\title{
HALHATATLANSÁG ÉS UNALOM
}

\section{IMMORTALITY AND BOREDOM}

\author{
Komlósi Andrea \\ PhD, óraadó, Eötvös Loránd Tudományegyetem Bölcsészettudományi Kar Filozófia Intézet \\ komlosi.andrea@gmail.com
}

\section{ÖSSZEFOGLALÁS}

Vajon nem magától értetődő-e, hogy ha lenne rá lehetőségünk, akkor az örök életet kellene választanunk? Talán nem az. Bernard Williams például úgy véli, a halandóságunkat feladva az elviselhetetlen unalom végtelen korszaka várna ránk, Samuel Scheffler szerint pedig az örök élet szükségképpen értelmetlen lenne, mivel az emberi élet minden értéke az élet mulandóságának köszönhető. Írásomban először a szükségszerű unalomból és a trivialitásból vett érvek elleni főbb megfontolásokat veszem szemügyre, majd vázolom, hogyan lenne érdemes a halhatatlanság mellett érvelni.

\section{ABSTRACT}

Is it not self-evident that we should choose to never die, given the option? Maybe it isn't. Bernard Williams argues that if we were to abandon our mortality, we would necessarily become unbearably bored. Furthermore, according to Samuel Scheffler, immortal life would be meaningless since our values depend on the temporal finitude of our lives. In this paper, I review the main challenges to the argument from necessary boredom and the argument from triviality, and outline a possible way to show the desirability of immortality.

Kulcsszavak: halhatatlanság, élet értelme, unalom, narratív azonosság, Bernard Williams, Samuel Scheffler

Keywords: immortality, meaning of life, boredom, narrative identity, Bernard Williams, Samuel Scheffler

\section{BEVEZETÉS}

Jelen állás szerint a halál elkerülhetetlen, és az élet rövid, ezért némelyek talán úgy érezhetik, hogy volna mit javítani a helyzeten. Egyesek szerint azonban a helyzeten kizárólag rontani lehetne, s ha van valami, ami tényleg végzetes lenne, az az örök élet elixírje. 
De vajon miért lenne olyan rossz az örök, de akár már egy nagyon hosszú élet is? Bernard Williams szerint például azért, mert elkerülhetetlenül unalmassá válna, olyannyira unalmassá, hogy aligha lenne lehetséges élni, Samuel Scheffler szerint pedig azért, mert elkerülhetetlenül értelmetlen lenne, olyannyira értelmetlen, hogy aligha lenne érdemes élni (Williams, 1973; Scheffler, 2013a).

Persze nem mindenki látja így. Valaki nem tudja elképzelni, hogy bármikor is megunná az életet, és úgy véli, aki nem üdvözli a halhatatlanság gondolatát, az valószínüleg eleve könnyebben unja el magát (Nagel, 1985). Némelyek pedig úgy vélik, nemhogy értelmes lehet egy örök élet, de biztosan értelmesebb is, mint bármelyik véges élet, mivel minden véges életre igaz, hogy kevesebb, számunkra kedves vagy éppenséggel objektíve értékes projektet tudunk véghezvinni, mint amennyire képesek lennénk, ha hosszabb idő állna rendelkezésünkre. Vagyis némelyek számára azért tünik értelmetlennek az élet, mert rövid, némelyek számára pedig akkor tünne annak, ha hosszú lenne.

A következőkben elöször a két fó érvet ismertetem, amely arról szeretne meggyőzni bennünket, hogy nem lenne érdemes feladnunk a halandóságunkat, majd rátérek a föbb ellenérvekre és az azokkal kapcsolatos problémákra, végül pedig vázolom, hogyan lenne érdemes a halhatatlanság mellett érvelni.

\section{MULANDÓSÁG VAGY ÖRÖK ÉLET}

Bernard Williams állítása, miszerint a halhatatlanság nem lehet vonzó, legalábbis számunkra, emberi lények számára, máig tartó vitát generált. Mielött azonban közelebbről vizsgálnánk meg Williams állítását, érdemes lehet néhány szót szólni arról, miben is állhatna a halhatatlanság tulajdonképpeni vonzereje.

A válasz persze nyilvánvaló: abban áll a vonzereje, hogy aki halhatatlan, az nem hal meg. A helyzet azonban mégsem ilyen egyszerü. Abban ugyanis, hogy a halál nem jó dolog, nagyjából egyetértés uralkodik. Aki úgy gondolja, hogy nem lenne érdemes feladni a halandóságunkat, az nem azért gondolja így, mert jó dolognak tartja a halált. Williams is a halandóságot tartja jó dolognak, nem magát a halált, sőt, egyetért azokkal, akik úgy gondolják, mindig jobb lenne élni. Csak azokkal nem ért egyet, akik úgy vélik, jobb lenne mindig élni.

Első pillantásra talán különösnek tünhet ez a kombináció. Ha belátjuk, a halál olyasmi, amit minden egyes pillanatban okunk van elhalasztani, akkor úgy tünhet, arra is okunk van, hogy örökre elhalasszuk, hiszen úgy biztosan teljesül az a kívánságunk, hogy mindig tovább éljünk. Williams azonban elutasítja ezt a konklúziót. Szerinte abból, hogy mindig okunk van arra vágyni, hogy éljünk, nem következik, hogy okunk van arra vágyni, hogy mindig éljünk.

De vajon miért nem? Mire vágyunk, amikor arra vágyunk, hogy tovább éljünk? Arra vágyunk, hogy ne korlátozzon minket a halál, hogy a jövő nyitott és tágas le- 
gyen, hogy benne határozatlan ideig folytathassuk szeretett projektjeinket, vagyis hogy egy ugyanilyen életet folytathassunk sokáig. Legalábbis a Williams állítása ellen érvelők többsége úgy veszi, hogy a halhatatlanságra vágyva nem vágyunk másra, mint egy ugyanilyen életre, csak beláthatatlanul hosszan, abból az életből szeretnénk többet, amivel már rendelkezünk, és éppen ezért elegendőnek tartják megmutatni azt, hogy mindig lehetségesek új projektek, amelyek az élet folytatására sarkallnak minket, illetve azt, hogy léteznek olyan projektek, amelyek kimeríthetetlenek.

De nem tudjuk pontosan, milyen lenne az örök élet. Valószínünek azonban nem tünik, hogy miután megittuk az örök élet elixírjét, egy pontosan ugyanilyen típusú életet folytatnánk a végtelenségig. Ha kiderülne, hogy tudunk repülni, akkor egy ideig még biztosan ugyanúgy caplatnánk le a boltba, mint eddig, megszokásból, de utána valami egészen más következne. És bár lehet vágyni egy olyan életre is, amelynek körvonalai szinte teljes homályban vannak, de egy ilyen vágy nem azonos azzal a hétköznapi vággyal, hogy a mostani életünket folytassuk tovább, és nem is következik belőle.

Egy dolog biztos: egyelőre nem rendelkezünk az örök élet elixírjével. És ez a tény rögtön magyarázatot is adhat arra, hogy miért foglalkozunk egyáltalán a kérdéssel. Azok számára, akik olykor elégedetlenek azzal, hogy csak egy véges élet jutott nekik, vigaszt nyújthat a gondolat, hogy talán nem is lenne érdemes feladnunk a halandóságunkat, mivel a halhatatlanság nem olyasmi, amire vágyni érdemes, mert bár az élet rövid, de még így is jobb, mint az öröklét, ami vagy elviselhetetlenül unalmas lenne, vagy nem is lenne emberi élet.

\section{3. ÉRVEK A HALANDÓSÁGUNK FELADÁSA ELLEN}

\subsection{Az elkerülhetetlen unalomból vett érv}

Az elkerülhetetlen unalomból vett érv Williamstől ered, aki a halhatatlanság unalmáról szóló írásában Karel Čapek Makropulosz-ügy című színműve főhősének, Elina Makropulosznak történetét idézi fel tézisét illusztrálandó. Elina, aki egy elixírnek köszönhetően sokáig s egyre boldogtalanabbul él, 337 év után úgy dönt, nem kér újabb adagot a szerből.

Williams tökéletesen érthetőnek találja Elina döntését, és erre két, egymást kiegészítő oka van. Az egyik, hogy Williams szerint a hosszú vagy örök életnek két kritériumnak kell megfelelnie ahhoz, hogy egyáltalán kecsegtető lehessen a számunkra. Egyrészt azonosnak kell lennünk azzal, aki örök életet él, másrészt az örök életnek olyannak kell lennie, amely adekvát módon kapcsolódik azokhoz a célokhoz, kategorikus vágyakhoz, amelyek miatt tovább szeretnénk élni. A másik ok pedig az, hogy Williams szerint amennyiben az 
örök élet mind a két feltételnek megfelel, akkor elkerülhetetlenül és elviselhetetlenül unalmas lesz. ${ }^{1}$

Ha az idő múlása ellenére nem változik a karakter, akkor ugyan nem vész el a személyes azonosság, de mivel minden karakterhez adott mennyiségủ kategorikus vágy tartozik, azokból előbb-utóbb óhatatlanul kifogy majd, újakra nem tehet szert, és beköszönt számára az elviselhetetlen és permanens unalom korszaka. ${ }^{2}$

Ezen az unalmon ugyan segíthetne, ha változások történnének a karakterben, és szert tenne újabb kategorikus vágyakra, viszont ezek a változások a jövőbeli személyt oly mértékben különbözővé tennék a mostanitól, hogy nagyjából annyi indoka lenne azonosítani magát vele, $\mathrm{s}$ az ö öröklétét és benne a vágyait a sajátjának tekinteni, mint amennyi indoka lehetne a szomszédja öröklétére vágyni.

Tehát Williams szerint semmiképpen nem lehet vonzó az örök élet, mivel minél inkább a sajátunknak tủnne, annál kevésbé lenne élhető, és fordítva, minél változatosabb és élhetőbb lenne, annál kevésbé tűnne a saját életünknek.

\subsection{A trivialitásból vett érv}

A második, halhatatlanságra vonatkozó szkeptikus érv Samuel Schefflertöl származik. Scheffler kiindulópontja az a belátás, miszerint az emberi életet olyan mértékben áthatja és formálja a temporális végesség ténye, hogy amennyiben ez a végesség megszűnne, akkor azok a fogalmak is értelmüket vesztenék, amelyek miatt értékesnek tartjuk az életünket, és amelyek miatt a meghosszabbítására vágyunk.

Veszteség, betegség, veszély, kockázat mind olyan fogalmak, amelyek tartalmuk jelentős részét abból a felismerésből nyerik, hogy az életünk időben korlátozott, hogy bármelyik percben meghalhatunk, és végül mindenképpen meg is halunk. Ha viszont a halál korlátja nélkül mindezen fogalmak jelentése megkérdőjeleződik, nem világos, mit jelenthetne a gyarapodás, az egészség, a biztonság vagy a bizonyosság. És mivel az emberi megfontolásokban kulcsszerepet játszanak ezek a fogalmak, hiszen döntéseink a végső szűkös erőforrás, az idő által ránk rótt határok között, a végesség háttere előtt zajlanak, így a halhatatlansággal egy olyan életet képzelünk el, amelyben nincsenek valódi emberi döntések.

Így azután az sem világos, hogy hogyan lehetnének emberi értékek egy ilyen életben. Ha igaz az, hogy a temporális szükösség kényszerít minket arra, hogy rangsoroljuk a lehetőségeket, és döntsünk az arra érdemesnek ítélt opció mellett,

\footnotetext{
${ }^{1}$ Williams kategorikus vágyaknak nevezi azokat a vágyakat, amelyek olyan központiak a karakter számára, hogy indokot adnak arra, hogy tovább éljen.

${ }^{2}$ A hagyományos értelmezésben Williams szerint azért köszönt be az unalom, mert nem tehetünk szert új kategorikus vágyakra, amennyiben változatlan a karakterünk. A későbbiek során visszatérek majd arra, hogy milyen egyéb értelmezési lehetőség áll még rendelkezésünkre.
} 
akkor e nélkül a választási kényszer nélkül nem világos, milyen értelmet lehetne egyáltalán adni az érték fogalmának. Ha az értékelő attitüd lényegi szerepet az emberi életben az időbeli szűkösség miatt játszik, akkor a halhatatlanság aláásná az értékelő attitűd meglétének feltételeit, és a döntéseink trivializálódnának.

Vagyis Scheffler nem állítja, hogy elviselhetetlen lenne az örök élet, csak azt mondja, hogy nem lenne érdemes élni, mivel triviális lenne és felszínes, csekély jelentőségü döntésekkel, mert a veszteségeket később pótolhatnánk, s ami elromlott, idővel kijavításra kerülne. És Scheffler úgy látja, egy ilyen élet a legkevésbé sem hasonlítana ahhoz, amit most emberi életnek tekintünk, s ilyenformán az a vágykép, hogy az élet, amelyet most élünk örökké folytatódjon, zavaros és elvben is elérhetetlen (Scheffler, 2013b, 207.). Tehát szerinte nem pusztán értelmetlen lenne az örök élet, hanem az örök emberi élet fogalma egyszerüen inkoherens.

\section{4. ÉRVEK A HALANDÓSÁG FELADÁSA MELLETT}

\subsection{Az elkerülhetetlen unalomból vett érv elleni megfontolások}

\subsubsection{Ismételhetö örömök és kimeríthetetlen projektek}

Jó kiindulópont lehet Timothy Chappell azon felvetése, mely szerint önmagukban a dolgok sem nem unalmasak, sem nem nem unalmasak, hanem csak egy személlyel való relációban válhatnak egyikké vagy másikká, továbbá, hogy a hétköznapi unalom esetében nem a kategorikus vágyak hiánya eredményezi az unalmat, hanem sokkal inkább az, hogy a kérdéses pillanatban azok közül a dolgok közül, amelyeket csinálni szeretnénk, semmit nem csinálhatunk (Chappell, 2007). Vagyis szerinte hétköznapi esetben mindig ahhoz képest tünik valamilyen tevékenység unalmasnak, amit egyébként szívünk szerint csinálnánk.

Léteznek azonban az unalomnak további típusai is, ismeri el Chappell. Az egyik további típus az, amelyik akkor bukkan fel, amikor éppenséggel nincs semmi, ami összecsengene a projektjeinkkel, merthogy nincsenek projektjeink, a másik pedig az, amelyik azért bukkan fel, mert a meglévő projektjeinket unjuk. Azonban, még ha elö is fordul olykor e két utóbbi unalomtípus, ezek nehezen tekinthetők indokolt unalomnak, állítja Chappell, mivel, ha azért unatkozunk, mert nincsenek projektjeink, akkor egyszerüen szereznünk kell egyet, ha pedig arról van szó, hogy minden projektünket unjuk, akkor az csak egy múló hangulat lehet. És lehetséges ugyan, hogy néhány búskomor halhatatlan ilyesféle érzések hatására feladja a projektekkel való foglalkozást mint olyat, de ettől ezek még nem jogos formái az unalomnak.

Tehát ha létezik jogos unalom, ahogyan Williams állítja, akkor annak az első típusú unalomnak kell lennie, amelynek viszont feltétele, hogy legyenek fáradozásra érdemes projektjeink, ha egyszer azokhoz képest látszik valami unal- 
masnak. Vagyis Williams víziója a végtelen, mindent átható unalomról Chappell szerint illúzió.

Első pillantásra kissé talán naivnak tünhet Chappell gondolatmenete. Azonban amennyiben úgy értelmezzük Williamst, mint aki azt állítja, hogy ha a karakterünk változatlan marad, akkor szükségképpen a végére érünk egyszer a kategorikus vágyaink kielégítésének, és semmi nem marad majd, ami arra sarkall minket, hogy tovább éljünk, de mégis kénytelenek lennénk a halhatatlanságunk miatt, és így beköszöntene az elviselhetetlen, végtelen unalom korszaka, akkor csak kétféle válaszlehetőség mutatkozik. Vagy azt állítjuk, hogy lehetnek olyan kategorikus vágyaink, amelyek kimeríthetetlen örömforrásokhoz kapcsolódnak, és akkor tényleg csak egy hangulat volt, hogy unatkoztunk, vagy azt, hogy mégiscsak változhat a karakterünk, és szert tehetünk újabb kategorikus vágyakra, és akkor tényleg, ha elunjuk magunkat, ideje váltani, és új vágyak után nézni.

És Chappell szerint az emberi élet legfontosabb projektjei, úgymint barátság és szerelem, a müvészetek élvezete és gyakorlása, kutatás és felfedezés, eleve kimeríthetetlenek (Chappell, 2007; Fischer, 1994). Persze ettől még lehetségesek kimerülő kategorikus vágyak és akár unalom is, de ha mindezek együtt vannak jelen a kimeríthetetlenek örömforrásokkal, akkor vonzó lehet a halhatatlanság. És ha jobban meggondoljuk, a mostani életünk is ilyenforma, úgyhogy miért is lenne más egy örök élet? Vagyis nem kell osztoznunk Williams félelmében, nem merülnek ki a kategorikus vágyak, és így nem szükségszerü az unalom egy olyan örök életben sem, amely Williams mindkét kritériumát kielégíti.

Hát igen, természetesen lehetséges, hogy valóban kimeríthetetlennek bizonyulnának a kategorikus vágyaink, de nem egyértelmü, hogy amennyiben a tét az örökkévalóságig tartó elviselhetetlen szenvedés, akkor érdemes lenne-e egy ilyen „talánra” bízni magunkat.

\subsubsection{Változó karakter}

A fent említett másik megoldási lehetőség az, ha elvetjük Williams második kritériumát, megmutatva azt, hogy noha a kategorikus vágyak változásával a karakter is változik, ez nem jár együtt sem a személyes azonosság megszünésével, sem pedig azzal, hogy érdektelennek találjuk a jövőbeli énünk sorsát.

Elöljáróban érdemes megkülönböztetni a minimális értelemben vett személyes azonosságtól a mélyebb értelemben vett személyes azonosságot. ${ }^{3}$ A minimális értelemben vett azonosságon értsük azt az azonosságot, amelyhez elégséges, ha továbbra is ugyanazzal az eredettel rendelkező emberi lények maradunk, mélyebb értelemben pedig akkor tekintsünk azonosnak két személyt, ha képesek saját magukként felismerni a másikat. Ha az örök élet során változik a karakterünk, akkor

\footnotetext{
${ }^{3}$ Hasonló distinkcióval él például Fischer, 2013; Goldie, 2011; Schechtman, 2001; Strawson, 2004.
} 
könnyen lehet, hogy ebben a mélyebb értelemben már nem leszünk azonosak a mostani önmagunkkal, a minimális azonosság azonban akkor is megmarad, már csak azon egyszerü oknál fogva is, hogy nem haltunk meg.

Williams figyelmét azonban aligha kerülte el a tény, hogy életünk során jelentős változásokon mehet keresztül a karakterünk anélkül, hogy a minimális azonosságunk megszünne, úgyhogy a problémát valószínủleg abban látta, hogy a minimális azonosság nem egy nagyon érdekes formája a személyes azonosságnak, mivel nincs okunk egy olyan jövőbeli valaki életére vágyni, aki csak minimális értelemben azonos velünk, akiben nem ismernénk fel magunkat. De ha nem vágyunk egy ilyen jövőbeli valakinek az életére, akkor arra nem vágyunk, hogy hosszabb életet éljünk, mert az hozzá vezet el. Vagyis nincs okunk vágyni még egy hosszabb életre sem, nemhogy a halhatatlanságra.

Ekkor - úgy tünik - két lehetőségünk van: (1) megmutatjuk, hogy a mély értelemben vett azonosság minden látszat ellenére sem szünik meg a kategorikus vágyak változásával, (2) megmutatjuk, hogy bár megszünik, de vágyhatunk egy olyan személy életét élni, aki csak a minimális értelemben azonos velünk. Én amellett érvelek, hogy a mély értelemben vett azonosság valóban megszünik a kategorikus vágyak változásával, viszont nem csupán a minimális azonosság marad meg, hanem egy harmadik, köztes formája az azonosságnak szintén megőrződik, és így mégiscsak lesz indokunk vágyni az örök életre.

A mély azonosság plauzibilis kritériuma lehet például az, hogy képesek legyünk empátiával fordulni korábbi önmagunkhoz, és ez egy olyan feltétel, amelynek nem felelhetünk meg úgy, ha megváltoznak a kategorikus vágyaink. ${ }^{4}$ Ahhoz, hogy ezt belássuk, vizsgáljuk meg, vajon mit kell az alatt érteni, hogy empátiával fordulunk korábbi önmagunkhoz.

Amennyiben empatikus hozzáféréssel rendelkezünk a múlthoz, akkor nem pusztán emlékszünk arra, hogy mi történt, hanem fel is tudjuk idézni az akkori érzelmeinket, meg tudjuk érteni, hogy hogyan viselkedhettünk úgy, ahogy. Nem egyszerüen felfogható számunkra az, hogy valaki képes úgy viselkedni, ám ez saját magunk számára tökéletesen idegen, hanem azok az érzések most is jelen vannak bennünk, a korábbi hiteinket és vágyainkat legitimként ismerjük fel, sőt, olykor egy-egy pillanatra még most is fontolóra vesszük, ne cselekedjünk-e azoknak megfelelően. De végül nem tesszük, mert már sok egyéb hittel, vággyal rendelkezünk, már sok egyéb dolgot is értékesnek tartunk.

\footnotetext{
${ }^{4}$ Lásd részletesen Schechtman, 2001. Marya Schechtman úgy véli, hogy a személyes azonosság narratív elméletei önmagukban nem elegendőek ahhoz, hogy a személy mély értelemben vett túléléséről a végső szót kimondják, részben azért, mert ugyan elmondható egy koherens történetként az, hogyan változott meg valaki tökéletesen, de könnyen lehet, hogy ez csak azt mutatja, hogy koherens történetet lehet mesélni arról, hogy valaki hogyan veszítette el az azonosságát. Ezért gondolja úgy Schechtman, hogy a narratív elméletet ki kell egészíteni a múlthoz való empatikus hozzáférés kritériumával.
} 
És amikor attól félünk, hogy a jövőben megszününk majd létezni, abban az értelemben, hogy a jövőbeli személy nem lesz azonos velünk, akkor attól félünk, hogy nem lesznek megfelelő módon reprezentálva a jövőbeli személyben a mostani szenvedélyeink és meggyőződéseink, ideáljaink nyomtalanul eltünnek. Vagyis ha elfogadjuk a mély azonosságnak eme feltételét, akkor az alábbi félelmünk lehet: itt vagyok most, ilyen vagyok, ehhez képest nagyon másmilyen lesz az, aki ezer év múlva a helyemen lesz. És lehet, hogy a változás fokozatosan történik majd, de ha nagyon másmilyen lesz az a valaki, akkor talán nem érez majd semmilyen empátiát az iránt, aki én vagyok most. Talán azt fogja gondolni, hogy az a valaki, aki én voltam, már rég nem létezik. És ha ezt gondolja majd, akkor igaza lesz, mert a mély értelemben vett túlélésem részben rajta múlik.

Az, hogy a jövőbeli személy én leszek-e, részben azon múlik, hogy ő hogyan viszonyul hozzám, és ha nem rendelkezik a megfelelő attitüddel felém, nem képes azonosulni velem, ha nem vagyok megfelelö módon jelen benne, akkor megszüntem létezni. Ahhoz, hogy a későbbi énem azt mondja, hogy még mindig ugyanaz vagyok, az szükséges, hogy a mostani vágyaim megfelelő módon kapcsolódjanak az ő vágyaihoz, mert ha nem, akkor idegennek fog érezni, és azt fogja mondani, hogy már nem létezem. Vagyis, ha megváltoznak a kategorikus vágyaink, akkor a jövőbeli személy úgy fogja érezni, hogy én már nem létezem. És ha így lesz, akkor a mély azonosság megszünik.

Nem biztos azonban, hogy érdemes a mély értelemben vett azonosság megörzéséhez kötni azt, hogy vágyunk-e az örök életre vagy sem, ugyanis a személyes fejlődés lehetőségéhez elengedhetetlennek tűnik, hogy változhassunk, akár radikális mértékben is. Tehát a személyes azonosság olyan kritériumára lenne szükségünk, amely biztosítja a lehetőségét annak, hogy éppenséggel nagyon is idegennek tủnjön számunkra a korábbi énünk. Connie Rosati egyenesen úgy gondolja, hogy nem is egyszerüen arról van szó, hogy változhatnak a kategorikus vágyaink, és nem is csak arról, hogy szükséges a változás a fejlődéshez, hanem arról, hogy autonóm cselekvő ágensként hozzánk tartozik az arra való képesség, hogy időről időre újragondoljuk magunkat, és döntsünk azzal kapcsolatban, hogy milyen emberekké szeretnénk válni. Éppen ettől vagyunk személyek (Rosati, 2013). Vagyis mintha épp az lenne elengedhetetlen ahhoz, hogy személyként létezzünk, hogy időről időre megszünjön a mély értelemben vett azonosságunk. Így nemcsak arról van szó, hogy nem szününk meg ugyanannak a személynek lenni, ha változunk, hanem arról is, hogy csak akkor vagyunk személyek, ha változhatunk.

Mindezek alapján azt mondhatjuk, hogy a személyes azonosság nem két, hanem inkább három szintjét érdemes megkülönböztetni: a minimális azonosságot, a mély azonosságot és a személy értelmében vett azonosságot, mely utóbbihoz elég, ha ugyanazok az autonóm ágensek maradunk. És ez utóbbi talán elégséges ahhoz, hogy vágyjunk a folytatásra. 


\subsubsection{Korlátozott memória}

Lehetséges azonban olyan módja is annak, hogy Williams konklúzióját elkerüljük, amely nem feltételez sem új, sem kimeríthetetlen kategorikus vágyakat. Többen felhívják a tényre a figyelmet, mely szerint az unalom szempontjából nem az események tényleges ismétlődése számít, hanem az, hogy mennyire tünnek ismétlődőnek (Greene, 2017; Belshaw, 2015). És mikor tűnhetnek ismétlődőnek? Például akkor, ha ismétlődnek, és emlékszünk is rájuk. Azonban könnyen érezhetjük akár az ismétlődő tapasztalatokat is újnak, ha nem emlékszünk, hogy már átéltük őket.

És nem szabad elfeledkeznünk arról a tényről, hogy az ember feledékeny lény, s arról sem, hogy nincs különösebb okunk azt feltételezni, hogy az elixír elfogyasztásával a memória radikális javulása is együtt jár. Úgyhogy talán észszerü úgy képzelni a helyzetet, hogy nagyjából olyan lenne, mint amilyen most, vagyis a közelmúltra jobban emlékeznénk, a távolabbira kevésbé, vagy pedig semennyire, és így újnak tủnhetne akárhány ismétlés, kimeríthetetlennek tünhetnének a kategorikus vágyak még akkor is, ha valójában nem azok. ${ }^{5,6}$

Ekkor azonban az a kérdés merül fel, vajon érdemes-e egy olyan örök életre vágyni, amelynek során azt sosem tapasztaljuk meg, hogy egy nagyon hosszú életet élünk, mivel sosem emlékszünk sokkal többre belöle, mint amennyire most emlékszünk, a mostani életünkből. Ha hiszünk Williamsnek, akkor talán azt kell válaszolnunk, hogy igen, érdemes, mert nem az a fontos, hogy azt megtapasztaljuk, hogy mindig élünk, hanem csak azt szeretnénk tapasztalni mindig, hogy élünk.

${ }^{5}$ Azzal a problémával most nem foglalkozom, hogy hogyan kell a tapasztalatokat indił viduálni, hanem egyszerủen feltételezem, hogy kétszer megmászni ugyanazt a hegyet azt jelenti, hogy két darab ugyanolyan típusú tapasztalattal rendelkezem, és azt is feltételezem, hogy a kategorikus vágyak tapasztalattípusokhoz kapcsolódnak. Vagyis, ha az egyik kategorikus vágyam az volt, hogy egyszer az életben felmásszak a Mount Everest csúcsára, és megtettem, akkor tovább már nem sarkall ez a vágy arra, hogy tovább éljek. Ha viszont egy idő után nem emlékszem arra, hogy már egyszer felértem a tetejére, akkor újra vágyhatok erre, és újra lesz okom tovább élni.

${ }^{6}$ A memória természetes módon korlátos voltával párhuzamosan feltételezhetjük, hogy a képzelőerő is hasonló módon korlátos lenne, mint amilyen most, és általában nagyobb jelentőséget tulajdonítanánk az időben közelebbi eseményeknek, mint a távoli jövőben lévőknek. Ha viszont ez így van, akkor a temporális szűkösséghez nem szükséges, hogy a jövő horizontja valóban zárt legyen, elég az is, ha annak tünik, mert nem foglalkozunk a távolabbi jövővel, hanem a mostanihoz hasonló, csak valamivel talán nagyobb temporális keretben éljük az életüket, hozzuk a döntéseket, és nem vagyunk semlegesek azzal kapcsolatban, hogy mi mikor történik meg. Az elgondolást bővebben lásd Belshaw, 2015, valamint Greene, 2017. 


\subsection{A trivialitásból vett érv elleni megfontolások}

\subsubsection{Az aktuális élet legközelebbi alternatívája}

Preston Greene arra kér bennünket, képzeljük el a halhatatlanságot oly módon, hogy leéljük az életünket úgy, ahogyan amúgy is leélnénk, de a végén halál helyett egy sajátos gépezetbe kerülve a további időt szakadatlan eufóriában töltjük. Greene nem vitatja, hogy valószínúleg indokolt lenne úgy gondolni, hogy az életünk eme második, gépben töltött része értéktelen lenne, a kérdés szerinte csak az, hogy vajon ettől értéktelenné válna-e a gépezetbe kerülés előtti része is. Nem valószínü, állítja Greene, hiszen, például a halál sem teszi semmissé az addigi élet értékét. Vagyis Greene szerint, ha már egyszer leéltünk egy értékes életet, akkor azon nem ronthat, bármi is történjék utána, úgyhogy a halhatatlanságot választva legfeljebb annyira járhatunk rosszul, mint amennyire halandóként.

És abban igaza is van Greene-nek, hogy abból, hogy triviális lesz az elixír elfogyasztása utáni, vagyis a váltás utáni élet, nem következik magától értetödő módon, hogy az előtte élt élet is az lesz, ha eredetileg nem volt az, ahogyan nem válna értéktelen cselekedetté az, ha odaadnánk az utolsó pénzünket a nehéz helyzetbe került barátunknak attól, hogy másnap megnyerjük a fönyereményt a lottón. Ráadásul eredetileg nem volt értéktelen az életünk, hiszen ahhoz képest lenne triviális az átváltás utáni élet, legalábbis az érv szerint.

De vajon ahhoz, hogy megmutassuk, érdemes lenne feladni a halandóságunkat, elégséges-e az, ha megmutatjuk, hogy a halandóként végigélt életszakasz nem válna értéktelenné? Úgy vélem, nem. Méghozzá azért nem, mert nem egyszerűen nem válna értéktelenné, hanem visszatekintve - ha igaza van Schefflernek abban, hogy ami utána jön, értéktelen - éppenséggel még inkább felértékelődne. És nem nyilvánvaló, hogy érdemes-e azért feladnunk a halandóságunkat, hogy utólag még értékesebbnek tünjön az az élet, amit halandóként éltünk. Úgyhogy talán érdemesebb lehet azt megmutatni, hogy az örök életre való átváltás után sem válna triviálissá az életünk.

\subsubsection{Strukturális szükösség}

Többféle lehetőség is kínálkozik arra, hogy megmutassuk, az értékelő attitüdhöz elengedhetetlen temporális szükösségnek nem szükséges feltétele a temporális végesség. Például rámutathatunk arra, hogy vannak olyan dolgok, amelyekröl egyszerüen le lehet késni. Ha fel akarunk fedezni valamit, világos, hogy elsőként kell ezt megtennünk, különben nem lesz miénk a felfedezés.

Luca Ferrero, aki szintén úgy gondolja, hogy a trivialitásból vett érv nem bizonyítja, hogy a halandóság konstitutív volna az emberi lét számára, az emberi élet folyását a következőképpen látja (Ferrero, 2015). Az életünk egy sajátos pályát ír le a számunkra lehetséges állapotok által kirajzolt térben, és ezt a pályát a döntéseink határozzák meg, és a lehetséges útvonalak alkotta hálózatnak vannak 
olyan részei, amelyek automatikusan elérhetetlenné válnak a döntéseink nyomán, és örökre elvesznek a lehetőségeink közül, függetlenül attól, hogy a jövőben milyen döntéseket hozunk majd, és így a lehetőség-költségek folyamatosan gyülnek és gyülnek, bármelyik ösvényt választjuk is. Ennek megfelelöen a döntéseink nyomán szükségképpen létrejön a lehetőségek szükössége, mivel a lehetőségeink köréből egyszer s mindenkorra kiesnek elemek. És ez a szükösség strukturális jellemzője a világnak, mivel csak a hálózat topológiáján múlik, azon, hogy mely alternatívák zárják ki egymást, és melyek nem helyettesíthetők mással.

Világos, hogy a lehetőségek eme strukturális szűkössége képes biztosítani a deliberációhoz és szubsztantív döntésekhez szükséges hátteret, és többek között a megbánásra is lehetőséget teremt, bár a strukturális szűkösség által kiváltott megbánás nem azon alapul, hogy úgy érezzük, rosszul döntöttünk, hanem csupán annak megnyilvánulása, hogy valamilyen értékes dolog visszafordíthatatlanul elveszett, méghozzá a világ ilyen szempontból legalábbis kedvezőtlen struktúrája miatt.

Ahogy láttuk, Scheffler szerint az értékes emberi életre jellemző fogalmak alapvető forrását azok a korlátok jelentik, amelyeket az időnk szükössége kényszerít ránk, és az időnk pedig azért szükös, mert halandók vagyunk. Ferrero viszont úgy gondolja, hiba szem elöl téveszteni a temporális szűkösség és temporális végesség közti különbséget. Ugyanis a temporális végesség involválja a temporális szűkösséget, de fordítva nincs így, mert lehet ugyan, hogy az időnk végtelen, de az az időintervallum, amely alatt bizonyos lehetőség nyitva áll elöttünk, véges.

És így a temporális szűkösség végső soron a lehetőségek szűkösségén múlik, nem pedig a temporális végességen. Vagyis, valójában Schefflernek azt kellene megmutatnia, hogy a temporális végességen múlik az élet értelmessége, és nem csupán a temporális szükösségen, mert az időbeli végesség csak annyiban járul hozzá az élet értelmességéhez, amennyiben maga is hozzájárul a strukturális szükösséghez. Ha számít, akkor ezért számít, de sem nem elégséges, sem nem szükséges feltétele a strukturális szükösségnek.

Persze felmerül a kérdés, hogy a világunkra tényleg a strukturális szükösség-e a jellemző, vagyis az, hogy folyamatosan és jóvátehetetlenül elveszítünk lehetöségeket. Ha igen, akkor ebben az univerzumban az értékelő attitűd szempontjából mindegy, hogy halandók vagyunk-e, vagy halhatatlanok, mert a döntések súlyának és a permanens veszteségeknek a ténye és tapasztalata nem a temporális szükösségen múlik, és pláne nem az időbeli végességen. Ha ez így van, akkor viszont nem állíthatjuk, hogy az egyetlen fogalmilag koherens létezési módot az ember számára a halandóság jelenti.

De természetesen lehetséges, hogy a világunkra inkább a strukturális bőség a jellemző, amelyben nincsenek lehetőségköltségek, tévedésen, késésen semmi nem múlik. És valóban, magától értetődőnek is szokás tekinteni, hogy egy vég- 
telenül hosszú létezés olyan létezés lenne, amelyet maximális strukturális bőség jellemez, amelyben minden lehetséges permutációja minden lehetőségnek előbb vagy utóbb bekövetkezik, s így nincs olyan lehetőség, amely valóban permanensen elérhetetlen lenne. Akik ebből indulnak ki, emberi létként felismerhetetlennek tekintik a halhatatlanságot, és ebben valószínüleg igazuk is van.

Csakhogy a trivialitás tézishez azt kellene igazolni, hogy a halhatatlanság szükségképpen maximális bőséghez vezet. Ez azonban nem a halhatatlanságon múlik, hanem az univerzumon. Vagyis a végtelen idő önmagában egyik modellt sem zárja ki, így az örök emberi élet fogalma nem inkoherens. Viszont ebböl még nem következik, hogy vonzó is, állítja Ferrero.

\section{MÉG EGYSZER UNALOMRÓL ÉS ELKÖTELEZŐDÉSRŐL}

John Martin Fischer és Benjamin Mitchell-Yellin megkülönböztetését kölcsönvéve azt mondhatjuk, hogy eddig csak tartalmi unalomról beszéltünk, létezik azonban motivációs unalom is (Fischer-Mitchell-Yellin, 2014). Ezért érdemes még egyszer feltenni a kérdést, hogy vajon mi a forrása Williams szerint az unalomnak egy örök életben.

Ha David Beglint követjük Williams értelmezésekor, akkor azt kell mondanunk, hogy Elina unalma nem abból fakad, hogy már minden megtörtént vele, ami megtörténhetett, úgyhogy az a kérdés, hogy kifogyunk-e a projektekböl, vagy hogy lehetnek-e újak, nem érinti a lényeget, és ilyenformán az eddig felidézett ellenérvek célt tévesztenek (Beglin, 2017).

Beglin szerint ugyanis abból fakad Elina unalma, hogy többé nem képes olyan módon kapcsolódni a környezetéhez, amely jelentőséggel bírna számára. És bár Williams nem explicit azzal kapcsolatban, hogy miért vezetne a halandóság feladása ilyen elidegenedéshez, de a válaszhoz némi támpontot mégis nyújt a szöveg. Ugyanis azt mondja Williams, hogy ahogyan az unalom jele lehet az oda nem figyelésnek, ugyanúgy az, hogy valaki nem unatkozik, szintén jele lehet annak, hogy nem reflektál a dolgokra, ezért akár egy halhatatlant is elégedetté tehetünk azzal, hogy megfosztjuk attól a tudatosságától, amely elégedetlenné tenné, mivel emlékeztetné arra, hogy voltak „más idők, más érdeklődések, más lehetőségek" (Williams, 1973, 87.). Így Williams, szemben Rosatival, nem pusztán nem gondolja, hogy a képességünk arra, hogy más lehetőségeket elképzeljünk, indokot adhat arra, hogy üdvözöljük a halhatatlanság lehetőségét, hanem éppen ellenkezőleg, úgy véli, ez indokot ad arra, hogy elutasítsuk.

Ahhoz, hogy megértsük, miért, vissza kell térnünk a trivialitásból vett érvhez. Beglin egyetért Schefflerrel abban, hogy a temporális szükösség kényszerít minket arra, hogy válasszunk a lehetőségek közül, mert amikor elköteleződünk 
valami mellett, akkor azokhoz a lehetőségekhez képest tesszük ezt, amelyeket nem választunk, és már nem is fogunk. Már láttuk, hogy kétséges a trivialitásból vett érv konkluzivitása, de most nem is ez a fontos.

Ugyanis Beglin talán valami erősebbet is állít, nevezetesen azt, hogy amennyiben feladjuk a halandóságunkat, akkor azt a lehetőséget adjuk fel vele, hogy az életünk valamiért élt élet legyen. Az időbeli végesség azzal jár, hogy az életünket tulajdonképpen az elköteleződéseink alkotják, a végesség miatt az elkötelezödéseink szimbolikus jelentőségre tesznek szert, és a halandóság feladásával azt adjuk fel, hogy ilyen jelentősége lehessen az elköteleződéseinknek. Az elköteleződés aktusa maga válik értelmetlenné, jelentőség nélkülivé.

És ennek nyomán a már megélt véges élet elköteleződéseinek súlya, jelentősége is szertefoszlik, a halandóság feladásával azt a jelentőséget is feladjuk, amit még régen, valamikor a projektjeinknek tulajdonítottunk. Lehet, hogy nem vesszük rögtön észre, hogy elveszítették az értelmüket, de egy idő után látjuk majd. És mivel emlékszünk más időkre, más érdeklődésekre, más lehetőségekre, jelentőssé válik ez a veszteség. Eljön az élettől való elidegenedés, Williams szóhasználatában az elviselhetetlen unalom korszaka.

\section{RÖVID TÖRTÉNETEK}

Beglin gondolatmenete alapján Ferrero megoldásával az a probléma, hogy bármennyire valódiak is lennének a strukturális veszteségek, mégsem számítanának. Minden veszteség végső soron érdektelen lenne, ahogyan minden nyereség is. Vagyis, bár Ferrero érve válasz lehet Scheffler trivialitásból vett érvére, az elköteleződésnek az a fajtája, amelyről Beglin beszél, tényleg a végességhez, ráadásul a rövid élethez kapcsolódik, és a strukturális szükösség ezt bizonyosan nem képes pótolni.

Azonban amennyiben elfogadjuk, hogy Scheffler trivialitásból vett érve abból a szempontból legalábbis megállja a helyét, hogy megragadja az emberi létezés egy, önmagában is elégséges feltételét, akkor Ferrero ellenérve elegendő annak cáfolatához, hogy az örök emberi létezés fogalma inkoherens.

És akkor érdemes még egy pillantást vetnünk Ferrero halhatatlanjaira. Az ő halhatatlanjainak életét már halandó korukban sem egyetlen nagy, átfogó narratíva határozza meg, hanem egymásra következő, egymást néha átfedő kis történetek. Egy ilyen struktúrával rendelkező életben viszont, mivel a dolgok kis történetekben jelen lévő, lokális jelentőségéből nem fakad robusztusabb elköteleződés, az olyasfajta unalom, mint amilyenröl Williams kapcsán Beglin beszél, nem szükségszerü, még halhatatlanként sem. Ebből pedig az következik, hogy nem pusztán felismerhető lenne emberi életként az örök élet, de akár vonzó is lehet. 


\section{IRODALOM}

Altshuler, R. (2016): Immortality, Identity, and Desirability. In: Cholbi, M. (ed.): Immortality and the Philosophy of Death. Rowman \& Littlefield Publishers, 191-203. https://philarchive.org/ archive/ALTIIA-3

Beglin, D. (2017): Should I Choose to Never Die? Williams, Boredom, and the Significance of Mortality. Philosophical Studies, 174, 8, 2009-2028. DOI: 10.1007/s11098-016-0785-1, https:// philarchive.org/rec/BEGSIC

Belshaw, C. (2015): Immortality, Memory and Imagination. The Journal of Ethics, 19, 3-4, 323-348. DOI: 10.1007/s10892-015-9203-8, https://www.researchgate.net/publication/284812462_Immortality_Memory_and_Imagination

Chappell, T. (2007): Infinity Goes up on Trial: Must Immortality be Meaningless? European Journal of Philosophy, 17, 30-44. DOI: 10.1111/j.1468-0378.2007.00281.x, https://www.rep searchgate.net/publication/229056157_Infinity_Goes_Up_On_Trial_Must_Immortality_Be_ Meaningless

Ferrero, L. (2015): Agency, Scarcity, and Mortality. The Journal of Ethics, 19, 3-4, 349-378. DOI: 10.1007/s10892-015-9207-4, https://www.researchgate.net/publication/284812288_Agency_Scarcity_and_Mortality

Fischer, J. M. (1994): Why Immortality is Not So Bad. International Journal of Philosophical Studies, 2, 2, 257-270. DOI: 10.1080/09672559408570794, https://wmpeople.wm.edu/asset/index/cvance/fischer

Fischer, J. M. (2013): Immortality. In: Bradley, B. - Feldman, F. - Johansson, J. (eds.): The Oxford Handbook of Philosophy of Death. Oxford: Oxford University Press, 336-354.

Fischer, J. M. - Mitchell-Yellin, B. (2014): Immortality and Boredom. Journal of Ethics, 18, 4, 353 372. DOI: 10.1007/s10892-014-9172-3, https://www.researchgate.net/publication/266857470 Immortality_and_Boredom

Goldie, P. (2011): Empathy with One's Past. Southern Journal of Philosophy, 49, s1, 193-207. DOI: 10.1111/j.2041-6962.2011.00067.x, https://www.researchgate.net/publication/230296645_Empathy_with_one's_past

Greene, P. (2017): Value in Very Long Lives. Journal of Moral Philosophy, 14, 4, 416-434. DOI: 10.1163/17455243-46810057, https://www.researchgate.net/publication/319479060_Value_in_ Very_Long_Lives

Kolodny, N. (2013): That I Should Die and Others Live. In: Kolodny, N. (ed.): Death and the Afterlife. Oxford: Oxford University Press, 159-173.

Nagel, T. (1985): Death. In: Nagel, T.: The View from Nowhere. Oxford: Oxford University Press, 223-230.

Rosati, C. S. (2013): The Makropulos Case Revisited: Reflections on Immortality and Agency. In: Bradley, B. - Feldman, F. - Johansson, J. (eds.): The Oxford Handbook of Philosophy of Death. Oxford: Oxford University Press, 355-390. DOI: 10.1093/oxford$\mathrm{hb} / 9780195388923.013 .0017$

Schechtman, M. (2001): Empathic Access: The Missing Ingredient in Personal Identity. Philosophical Explorations, 2, 95-111. DOI: 10.1080/10002001058538710, http://chc.ucsd.edu/MCA/ Mail/xmcamail.2016-07.dir/pdfCaUwdXQEwa.pdf

Scheffler, S. (2013a): Death and the Afterlife. In: Kolodny, N. (ed.): Death and the Afterlife. Oxford: Oxford University Press, 15-110.

Scheffler, S. (2013b): Death, Value, and the Afterlife: Responses. In: Kolodny, N. (ed.): Death and the Afterlife. Oxford: Oxford University Press, 177-207. 
Strawson, G. (2004): Against Narrativity. Ratio, 17, 4, 428-452. DOI: 10.1111/j.14679329.2004.00264.x, http://lchc.ucsd.edu/mca/Paper/against_narrativity.pdf

Williams, B. (1973): The Makropulos Case: Reflections on the Tedium of Immortality. In: Williams, B.: Problems of the Self. Cambridge: Cambridge University Press, 82-100. https:// wmpeople.wm.edu/asset/index/cvance/williams 